\title{
Liminal Evrenin Ardından: Kümülatif Turistik Deneyimler Temelinde Kalıcı Davranışsal Edinimler ${ }^{1}$
}

\author{
Çağr1 ERDOĞAN² ve Said KINGIR ${ }^{3}$
}

\section{$\ddot{\mathrm{O} z}$}

Kümülatif bakıldığında yaşam içinde aralıklı bir yapı arz eden ve tekil bir faaliyet olarak düşünüldüğünde geçici nitelikte olan turistik deneyimlerin davranışsal edinim bağlamında ne gibi kalıcı etkiler bırakabileceği sorusundan hareketle araştırma kurgulanmıştır. Çalışma kapsamında nitel araştırma yöntemlerinden çoklu durum çalışması tekniği ile araştırma yürütülmüştür. Maksimum çeşitlilik örneklemesi dâhilinde gerçekleştirilen kırk beş yüz yüze görüşme sonrasında elde edilen yarı yapılandırılmış mülakat kayıtlarının incelenmesiyle veri sağlanmıştır. Tüm analiz işlemlerinde, nitel ve karma yöntemler için bilgisayar destekli bir veri analiz programı olan MAXQDA-Analytics-Pro v.18.2'den faydalanılmıştır. Sonuç olarak konuşma üslubu, giyim tarzı, yeme-içme şekli/alışkanlığ1 ve alan kullanım tercihi gibi gündelik yaşamın geneline sirayet eden davranış kalıplarının edinilmesine ek olarak; taşıt kullanım tercihi ve sıklığı, profesyonel yaşamın zenginleşmesi/baskılanması, tatil pratiği ve tatile çıkma sılılı̆ı gibi belirli faaliyetler odaklı davranışların öğrenilmesi ve bunların yerleşik hale getirilmesi noktasında da turistik deneyimlerin dikkate değer bir payı teşkil edebildiği anlaşılmışır. Buradan hareketle, bir olağandışı/paylaşılmayan çevre unsuru olarak turistik deneyimlerin birey için farklı yaşam pratiklerinin mümkün olduğunu gösteren, hareket alanını arttıran değerli bir etken olduğunun ifade edilmesi mümkündür.

Anahtar Kelimeler: Turistik Deneyim, Gündelik Yaşam Pratikleri, Davranışsal Edinim, Turist Psikolojisi, Turist Davranışı

\section{After the Liminal Stage: The Permanent Behavioral Acquisitions Based on Cumulative Touristic Experiences}

\begin{abstract}
The present work is based on the question of what kind of permanent effects touristic experiences, which have an intermittent structure in our life and which are temporary when considered as a single activity, may have permanent effects in the context of behavioral acquisition. Within the scope of the study, research was conducted with the multi-case study technique, one of the qualitative research methods. Data were obtained by examining the semistructured interview records obtained after forty-five face-to-face interviews conducted within the scope of maximum diversity sample. In all analysis processes, MAXQDA-Analytics-Pro v.18.2, a computer-aided data analysis program, was used for qualitative and mixed methods. As a result, in addition to the acquisition of behavioral patterns such as speaking style, dressing style, eating-drinking style / habit and area usage preference, which spread throughout daily life; It is understood that touristic experiences can have a significant share in learning and establishing certain activities-oriented behaviors such as vehicle usage preference and frequency, enrichment / suppression of professional life, holiday practice and frequency of going on vacation. From this point of view, it is possible to state that touristic experiences, as an extraordinary / unshared environmental element, are a valuable factor that shows that different life practices are possible for the individual and increases the range of action.
\end{abstract}

Key Words: Touristic Experience, Daily Life Practices, Behavioural Acquisition, Tourist Psychology, Tourist Behaviour

\section{Atıf İçin / Please Cite As:}

Erdoğan, Ç. ve Kıngır, S. (2021). Liminal evrenin ardından: Kümülatif turistik deneyimler temelinde kalıc1 davranışsal edinimler. Manas Sosyal Araștırmalar Dergisi, 10(1), 591-607.

Geliş Tarihi / Received Date: 07.02.2020

Kabul Tarihi / Accepted Date: 24.09.2020

\footnotetext{
${ }^{1}$ Bu çalışma Sakarya Uygulamalı Bilimler Üniversitesi Lisansüstü Eğitim Enstitüsü Turizm İşletmeciliği Anabilim Dalı'nda Prof. Dr. Said KINGIR danışmanlı̆̆ında yürütülmüss ve 23.05.2019 tarihinde savunması yapılmış olan "Turistik Deneyimlerin BenlikKavramı ile İlişkisi” başlıklı doktora tezinden üretilmiştir.

2 Dr. - Sakarya Uygulamalı Bilimler Üniversitesi Turizm Fakültesi, cagrie@sakarya.edu.tr

(iD ORCID: 0000-0001-9308-0182

3 Prof. Dr. - Sakarya Uygulamalı Bilimler Üniversitesi Turizm Fakültesi, saidkingir@subu.edu.tr

iD ORCID: 0000-0002-5459-3484
} 


\section{Giriş}

Rutinlerin, ciddiyetin, zamanla yarışın ve bunların sürekliliği bakımından bir anlamda sıradanliğın dünyasını temsil eden gündelik yaşamın karşısına;ritüel, oyun ve rahatlama anahtar kelimelerini de barındırması bakımından (Graburn, 1983) olağandışılığı vurgulayan turistik faaliyetler (Edensor, 2000, s. 325) yerleştirildiğinde, bu iki unsurun arz ettiği zttllğın yoğunluğu göze çarpacaktır. Ancak Edensor'un (2000, s. 341; 2001, s. 59) ifadesinden ve Jafari'nin (1987) modellemesinden de anlaşlabileceği gibi; gündelik yaşam ve turizm her ne kadar aynı zaman ve yeri işgal etmese ve dolayısıyla bir arada bulunmasa dahi, devamlılık arz eden dalgalı bir yaşam çizgisinin farklılaşan noktalarını temsil etmektedir. Nitekim Turner (1991, s. 97); her birey için özdeş tezahür etmeyecek olmasına karşın yapısı gereği inişli-çıkışl, zıtlıkları barındıran doğal bir döngü olarak sosyal yaşamı tasvir etmekte, böylelikle bahsi geçen yaşamsal bütüne ve etkileşimliliğge de ş̧ık tutmaktadır.

Gündelik yaşamın rutin sıradanlığının sürmesi aynı zamanda bu çevreden uzaklaşma ihtiyacının da yakıtı olmaktadır. Yakıtın pistonları harekete geçirmesiyle yaşamın bütünselliğindeki olağanlığın sunduğu grilik, periyodik bir yapı arz eden turistik faaliyetler aracilığıla kesintiye uğratılmakta, turistik deneyimlerin davet ettiği bilinmeyenlerle daha geniş bir renk skalasına erişim mümkün olmaktadır. Bu husus Jafari’nin (1987) bahsi geçen sıradanlığ1/gündelik yaşamı, sıra-dışı dünyaya doğacak olan turiste gebe olan bir rahme benzetişini akıllara getirmektedir. Ne var ki turist doğduktan sonra, esasen tekrar rahme dönmemektedir. Zira bu doğa dışı bir durumdur, ancak turistik deneyimlerin kati surette hiçbir tesirinin olmaması, varlığıyla yokluğunun tam anlamıyla bir olması halinde düşünülebilecektir. Elbette bu oksimoron ${ }^{4}$ ifadeden kasıt her bir turistik faaliyetin zorunlu olarak derin bir dönüşümü içerecek tesiri barındırdığını iddia etmek değildir. Bilakis geçici bir kesitte oyunsal bir anonimlik düzlemi sağlayıcı olarak turistik deneyimlerin -özellikle kümülatif ölçekte- yalnızca turizm oyununun nasıl oynandığı ile sınırlı olmayıp aynı zamanda gündelik yaşam pratiklerine taşan şekillendirici etkiler ortaya çıarıcı yönünün gözden kaçırılmasına mani olma niyetidir. $\mathrm{Bu}$ noktada turistik faaliyet esnasındaki bireye kısa bir bakış atmanın yerinde olacağı düşünülmektedir.

Turist rolünün aktif olduğu -Van Gennep'ın (1960) liminal/treshold evresine denk gelen- bu sıra dişı süreçte, Aktaş Polat'ın (2015) da mercek tutmuş olduğu gibi; standart davranış kalıpları terk edilmektedir. Turizm oyununun ritüelistik/ritüel-vari sınırları çerçevesinde beliren yeni normlar kapsamında yaşananlar, gündelik yaşama dönüldüğünde, haliyle büyük ölçüde görünmez olacaktır. Buna karşın söz konusu oyun, gündelik yaşam normlarının hiç olmazsa esnetilmesine, yeniden yorumlanmasına vesile olarak bu norm prizmasından geçen yansıya çeşitlilik imkânı kazandırabilecektir (Desforges, 2000; White ve White, 2004; Pocock ve McIntosh, 2011; Bond ve Falk, 2013; Pearce ve Packer, 2013). Öyleyse terk edilmiş olan standart davranış kalıplarının yerine, kısa süreliğine görülen ve geçici nitelikte olan liminoid davranışlar sergilense ve turist rolünün oynandığ1 süreçteki deneyimler son bulsa dahi; bu deneyimlerin birikimsel ölçekte -güçlü ya da zayıf olacak şekilde- yalnızca turistik yahut gündelik yaşama değil bir bütün olarak bireyin yaşamına yansımalarının olması beklenecektir.

Kuşkusuz yaşamdaki her deneyimin fizyo-psikolojik etkisi olacak,yaşanılan ve yaşayan ilişsisi kurulabilecektir. Turistik deneyimlerin bu hususta araştırma konusu olarak mercek altına alınmasındaki amaç; eşsiz/unique, kendine has/specific ve bireysel/individual çevre olarak da adlandırılan bir paylaşılmayan çevre (Plomin, 2011, s. 583) unsuru olarak turistik deneyimlerin, davranıssal edinim bağlamındaarz ettiği kalıcı tesirlerin literatürdeki işaret edicilerinden hareketle (Dann, 1977; Uriely, 2005; Edensor, 2007; J. Larsen, 2008) somut örneklerinin gün yüzüne çıkarılmasına katkı sağlanmasıdır. Böylece belirli açılardan temassız ve zıt iki parça olarak görünmesine rağmenturizmin gündelik yaşam pratikleri ile ilişkisine de kısmen 1şık tutulmuş olacaktır.

\section{Kavramsal Çerçeve}

Çalışma boyunca bahsi geçen kavramlara dair daha geniş okumalar yapılmasına ve konuya gösterilecek olası ilginin getireceği bilgi arayışının giderilmesine yönelik kaynakçadaki çalışmaların ziyaret edilmesi uygun olacaktır. Yine de bir araştırma makalesi olmasına rağmen çalışmada, yürütülmüş olan araşıırma çıtılarının anlaşılabilirliğinin desteklenmesi amacıyla birkaç temel kavramın kısa açıklamalarına yer verilmesi uygun görülmüştür.

\footnotetext{
${ }^{4}$ Mantıksal tutarlılığın bozulmasına işaret eden (Horn, 2018) ve Türk Dil Kurumu (TDK)'na göre “zıt anlamlı iki kelimenin bir arada kullanılması" olarak karşıllığ verilen oksimoron (TDK, 2020a); "çelişkili veya uyumsuz unsurlar kullanılarak oluşturulan kavram, şey" olarak da ifade edilmektedir (Merriam-Webster, 2020).
} 
Turistik Deneyim: Esasen bireyin katılım gösterdiği turistik faaliyet temelinde turist rolünü oynadığ1 süreçteki deneyimlerinin toplamı olarak ifade edilebilecektir.Ancak söz konusu deneyimin Quan ve Wang'in (2003) dikkat çektiği gibi; pazarlama-ve-işletme ile sosyal bilim açısından farklı görünümleri mevzubahistir. İlk açıdan turistik deneyim, bir tüketici deneyimiyken; ikinci açıdan gündelik yaşamdan önemli ölçüde farklılaşan bir zirve deneyimi/peakexperiencedir. İki farklı yaklaşım arasından bu çalışmada turistik deneyim, daha çok bir zirve deneyimi olarak ele alınmışır. Bu yaklaşımla paralellik arz eder niteliktedeneyim sürecinin birey bazında eşsizliğini vurgulamış olan Volo (2009, s. 120) turistik deneyimin, turistin zihnî mekânında gerçekleştiğinin üzerinde durarak, odaklanılmış olan coğrafi mekândan ötürü bulanıklaşmış hale gelen zihnî mekânın (bununla birlikte turistin ve psikolojik süreçlerin de (S. Larsen, 2007)) ön plana çıkmasına katkı sağlamıştır. Nitekim zihnî süreçleri, belleği ve anıları önceleyen S. Larsen (2007, s. 15) turist deneyimini; "uzun dönemli bellekte yer edinebilecek kadar güçlü, geçmiş seyahate ilişkin kişisel bir olay" şeklinde tanımlayarak turistik faaliyetin temel öznesi pozisyonundaki turisti merkeze alarak bir çerçevelendirme yapmıştır.

Paylaşılmayan Cevre: Tüm davranış kalıplarının, iç içe geçmiş bir yapı arz eden kalıtsal ve çevresel etkenlere (Smith, Hoeksema, Fredrickson ve Loftus, 2012, s. 483) dayandığ hususunda fikir birliğine varılmıştır (Bozcuk, 2005, s.283; Feldman, 1997, s. 323). Davranışsal genetik çalışmalarında bir etken olarak kalıtımın sabitlenebilmesi bakımından kardeşler, ikizler, özellikle de birbirinin genetik kopyası olan tek yumurta ikizleri üzerine çalışmalar yapılarak gelişimde çevresel faktörlerin etkisi tespit edilmeye çalışlımıştır (Turkheimerve Waldron, 2000; Plomin, Asbury ve Dunn, 2001). Bu bağlamda aile üyeleriyle paylaşılmayan, onlardan farklı bir şekilde çevresel etkenlerin deneyimlendiği, daha bireye özgü olarak nitelendirilebilecek çevre, paylaşılmayan çevre olarak adlandırılmaktadır (Plomin, Chipuer ve Neiderhiser, 1994, s. 2). Bu çalış̧mada aile bireyleri içinden bir diğeriyledeğil, bireyin zamansal düzlemde kendi önceki hallerine (deneyimler toplamına) kıyasla farklılaşması incelendiğinden; kişinin daha önceki deneyimlerinden belirli ölçüde ayrışan, benzersizliğiyle ön plana çıkan rutin-dış1/aşina olunmayan deneyimler kast edilmiştir. Nitekim burada Desforges (2000), Noy (2004) ve Cohen'in de (2011) üzerinde durmuş olduğu gibi, turistik deneyimlerin eşsiz, aşina olunmayan yönleri bakımından bireyin kendini değerlendirmesine, tanımasına imkân sağlayıcı ve genel boyutta yaşama anlam katıcı tarafları araştırma konusu edilmiştir.

Davranıssal Edinim: TDK (2020b) tarafından "edinim" kelimesine "kazanma, iktisap" ifadesiyle açıklık getirilirken, Amerikan Psikoloji Derneği Sözlügü/AmericanPsychologicalAssociation/APA Dictionary (2020) tarafindan"yeni bir davranışın, bilginin ya da becerinin kazanılması ya da bunun meydana geldiği süreç" olarak tanımlanmıştır. Dolayısıyla "davranışsal edinim", çalışma kapsamında; davranışla ilgili yeni bir kazanım sağlanması olarak kabul edilmiş ve ele alınmıştır.

Liminal Evre: Yaşamdaki önemli geçiş ritüellerindeki/rites of passage evreler üstünde duran Van Gennep (1960) liminal öncesi/preliminal, liminal/eşiksel/liminal, liminal sonrası/postliminalolmak üzere üç aşama ortaya koymuştur. Söz konusu ikinci aşama, ilk aşama olan ayrllmaya/separation ve son aşama olan birleşmeye/incorporationnazaran belirsizliği, arada kalmışlı̆̆1 vurgulayan bir geçiş/transitionritüelidir (Turner, 1991, s. 94-95). Turistik deneyimlerin de, aşina olunan gündelik yaşamın ve standart davranış kalıplarının terk edilmesini destekleyen yönüyle, bireyi liminal evreye geçiren bir geçiş ritüeli olarak değerlendirildiği bilinmektedir (Aktaş Polat, 2015; Conti ve Heldt Cassel, 2020).

Liminoid: Van Gennep'ın daha çok kabile ve tarım toplumları (Durkheim'inmekanik dayanısma toplumu) çerçevesinde ve dini ritüeller zemininde kavramsallaştırdığı geçiş ritüellerini, Turner modern toplumlara (Durkheim'ınorganik dayanıs̆ma toplumuna) uyarlamış ve dini zemini daha çeşitli gerekçelere açarak söz konusu eşikte olma durumunu "liminal-benzeri/liminal-likee" anlamında liminoid/ liminoid olarak terimselleştirmiştir (Turner, 1974; Bigger, 2009). Bu bağlamda gündelik yaşam normlarının askıya alındığ1 turist rolünün aktif olduğu geçici süreç "liminoid dönem" olarak ifade edilmiştir (Aktaş Polat, 2013; Aktaş Polat, 2015).

\section{Yöntem}

Yalnızca evi değil, gündelik yaşamı da bir anlamda dışlayan, sekteye uğratan, ters-yüz eden ve zaman dışı kılmak suretiyle biçimsizleştiren (Gottlieb, 1982, s. 167-170) turistik faaliyetler araciliğıyla somutlaşan alternatif dünyaya/paylaşılmayan çevreye (Dann, 1977) ilişkin sıra-dışı ve köksüz olarak etiketlenebilen deneyimlerin ne gibi kalıcı davranışsal etkileri olduğu sorusundan hareketle araştırma kurgulanmıştır. Derinlemesine bir incelemeyi desteklemesi açısından nitel araştırma yöntemi takip edilmiş ve araştırma çoklu durum çalışması tekniğiyle yürütülmüştür. Araştırma kapsamında konunun daha geniş bir çerçevede 
aydınlatılabilmesi amacıyla ise katılımcıların heterojen bir yapı sergilemesi hususunda gayret gösterilmiş, amaçlı örnekleme türlerinden maksimum çeşitlilik örneklemesi yoluyla veri elde edilmiştir.

Yürütülen araştırmada akran incelemesi, dış denetim (Creswell, 2016, s. 250-253) ve veri kaynağ1 üçgenlemesi (Yin, 2013, s. 323-324) uygulanmıştır. Bununla birlikte araştırma boyunca kullanılan verilere ilişkin her türlü maddi ve dijital materyallerin muhafaza edilerek teyit edilebilirliğin sağlanmasına yönelik hassasiyet gösterilmiştir.

Mülakatların 9'u Sakarya, geriye kalan 36'sı İstanbul ilinde kamuya açık alanlarda gerçekleştirilmiş, böylece toplamda gerçekleştirilen 45 mülakat aracilığıla veri elde edilmiştir. Söz konusu ham veriler; 04.01.2019 tarihinden 04.02.2019 tarihine kadar yapılan mülakatlar çerçevesinde gerçekleştirilen alan araşıırması vasıtasıyla sağlanmışıı. Yaş ortalaması 34,7 (yaş aralığı: 18-65) olarak tespit edilen katılımcıların örtülü onayının alınmasının ardından gerçekleştirilmiş olan görüşmelerin ortalama süresi 22 dakika 25 saniye (süre aralığı: 8 dakika 45 saniye-49 dakika 10 saniye) olmuştur. Bu hususta daha fazla detayı barındıran, katılımcılara ait demografik ve diğer bilgilerin aktarıldığı Tablo 1'e bulgular başlığı altında yer verilmiştir.

Turistik deneyimlerin benlik-kavramı ile ilişkisinin ortaya konulabilmesi doğrultusunda veri toplama aracı olarak hazırlanmış yarı yapılandırılmış mülakat formu kapsamında ${ }^{5}$ yer alan ve bu çalısmanın araştırma sorusuna cevap veren nitelikteki; katılımcılar için seyahatin/tatilin ifade ettiği anlamı, seyahatlerde/tatillerde yeniliğe açıklık seviyesini, destinasyondaki turistik unsurlarla ne şekilde ve yoğunlukta etkileşime geçildiğini, seyahat/tatil deneyimleri süresince gündelik yaşam alıskanlıklarının ne ölçüde talep/takip edildiğini ve bu deneyimlerin gündelik yaşam pratikleri üzerindeki süregelen etkilerini anlamaya ve ortaya koymaya yönelik olan sorular, yürütülen çalısma için veri toplama aracının temelini teşkil etmiştir.

Davranışsal edinim ana-teması literatür kaynaklı/kavrama-dayalı; gündelik yaşam, etkisiz ve tatil alışkanlığı temaları ise veriler 1şığında/veriye-dayalı oluşturulmuştur. Yine, gündelik yaşam temasının kodlarını ifade eden; beslenme/damak tadı, genel, meslek, giyinme ve ulaşım kodları da veriye-dayalı şekilde tasarlanmıştır. Bulgular kısmında yer verilmiş olan ilgili veri alıntıları ziyaret edilerek ana-temanın ham içeriği hakkında bilgi edinilmesi mümkün kılınmış, aynı zamanda verilerin şeffafllğı da sağlanmıştır. Bulgular kısmında verilen ilişki haritasının ve her koda ilişkin veri alıntılarının ayrı ayı başlıklandırılarak aktarılmasının ana-temanın içeriği hakkında yeterli açıklamayı ifade edeceği düşünülmüştür.

Verilerin kodlanmasından, durum/vaka modelleri temelinde ilişki haritalarının oluşturulmasına kadar içerik analizi yapılmasını kolaylaştıran tüm analiz işlemleri, nitel ve karma yöntemler için bilgisayar destekli bir veri analiz programı olan MAXQDA Analytics Pro v.18.2 aracilığılla tamamlanmıştır.

\section{Bulgular}

Turistik deneyimler ile davranışsal edinim arasındaki ilişki haritasından önce; katılımcılara ait bazı demografik ve ilgili diğer bilgileri içeren Tablo 1'e ve davranışsal edinim ana-temasının tema ve kod dağglımlarını ifade eden Şekil 1'e yer verilmesinin daha uygun olacağı düşünülmüştür.

\footnotetext{
5 İlgili formun tam metin örneğine ulaşmak için çalışmanın üretilmiş olduğu doktora tezinin ekler kısmına bakınız.
} 
Tablo 1. Katılimculara Ait Demografik ve Diğer Bilgiler

\begin{tabular}{|c|c|c|c|c|c|c|c|}
\hline 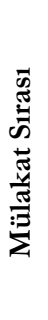 & 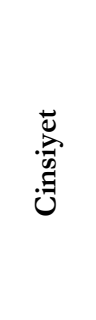 & 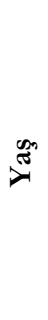 & 浔 & 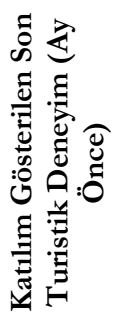 & 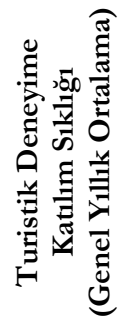 & 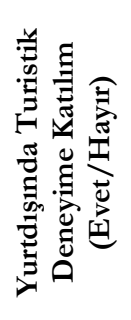 & 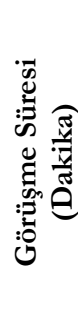 \\
\hline 1 & Kadın & 35 & Lisansüstü & 6 & $3-4$ & Evet & 32.56 \\
\hline 2 & Kadın & 31 & Lisansüstü & 12 & $2-3$ & Hayır & 23.06 \\
\hline 3 & Erkek & 36 & Lisansüstü & 5 & $2-3$ & Evet & 34.00 \\
\hline 4 & Kadın & 29 & Lisans & 12 & $3-5$ & Evet & 31.39 \\
\hline 5 & Erkek & 38 & Lisansüstü & 3 & $0,5^{6}$ & Evet & 31.37 \\
\hline 6 & Erkek & 28 & Lisans & 6 & $2-3$ & Evet & 19.47 \\
\hline 7 & Erkek & 29 & Lisans & 1 & $5-6$ & Evet & 46.01 \\
\hline 8 & Erkek & 29 & Lisans & 5 & $6-7$ & Evet & 13.12 \\
\hline 9 & Kadın & 33 & Lisans & 2 & $5-6$ & Hayır & 18.14 \\
\hline 10 & Kadın & 28 & Lisans & 6 & $6-7$ & Evet & 23.52 \\
\hline 11 & Erkek & 63 & Lisansüstü & 6 & $1-2$ & Evet & 20.19 \\
\hline 12 & Kadın & 28 & Lisans & 4 & $6-7$ & Evet & 27.50 \\
\hline 13 & Erkek & 35 & Lisans & 7 & $1-2$ & Evet & 23.00 \\
\hline 14 & Kadın & 50 & Lisansüstü & 4 & $5-6$ & Evet & 22.26 \\
\hline 15 & Kadın & 26 & Lisans & 4 & $6-7$ & Evet & 18.41 \\
\hline 16 & Kadın & 35 & Lisansüstü & 3 & $7-8$ & Evet & 22.27 \\
\hline 17 & Kadın & 47 & Ortaokul & 3 & $7-8$ & Evet & 21.13 \\
\hline 18 & Erkek & 40 & Lisansüstü & 5 & $8-9$ & Evet & 49.10 \\
\hline 19 & Erkek & 36 & Lisansüstü & 6 & $20-25$ & Evet & 36.38 \\
\hline 20 & Erkek & 38 & Lisansüstü & 6 & $1-2$ & Hayır & 47.37 \\
\hline 21 & Erkek & 18 & Ortaokul & 5 & $3-4$ & Hayır & 14.00 \\
\hline 22 & Kadın & 34 & Lisans & 2 & 40 & Hayır & 10.14 \\
\hline 23 & Erkek & 41 & Lisans & 3 & 35 & Hayır & 19.12 \\
\hline 24 & Erkek & 40 & Lisans & 1 & 50 & Evet & 16.00 \\
\hline 25 & Erkek & 30 & Lisans & 1 & $12-15$ & Evet & 08.45 \\
\hline 34 & Kadın & 30 & Lisans & 6 & $2-3$ & Hayır & 13.45 \\
\hline 35 & Kadın & 65 & Lisans & 4 & $1-2$ & Evet & 17.00 \\
\hline 36 & Erkek & 19 & Lise & 1 & 10 & Hayır & 33.00 \\
\hline 37 & Kadın & 35 & Lise & 5 & 1 & Hayır & 09.15 \\
\hline 38 & Erkek & 26 & Lisans & 7 & $3-4$ & Hayır & 13.41 \\
\hline 39 & Erkek & 31 & Lisans & 20 & 10 & Hayır & 28.17 \\
\hline 40 & Kadın & 49 & Lise & 2 & 6 & Evet & 10.54 \\
\hline 41 & Kadın & 59 & Lise & 6 & $3-4$ & Hayır & 15.05 \\
\hline 42 & Kadın & 35 & Lisans & 1 & 1 & Hayır & 18.00 \\
\hline 43 & Kadın & 28 & Lisansüstü & 3 & $12-13$ & Evet & 21.28 \\
\hline 44 & Erkek & 24 & Lise & 6 & 10 & Evet & 11.50 \\
\hline 45 & Kadın & 34 & Lisansüstü & 1 & $3-4$ & Evet & 18.31 \\
\hline
\end{tabular}

Yukarıdaki Tablo 1'de "Katılım Gösterilen Son Turistik Deneyim (Ay Önce)" sütunu, katılımcıların en son tatilinden itibaren kaç ay geçmiş olduğuna dair ifadelerini yansıtmaktadır. "Turistik Deneyime Katılım Sıklığı (Genel Yıllık Ortalama)" kısmı, katılımcıların turistik deneyime geçmişte ne sıklıkla katıldıklarını düşünerek, genel olarak yılda ortalama kaç defa seyahate/tatile çıktıkları sorusuna verdiği yanıt1 içermektedir. "Görüşme Süresi (Dakika)" sütununda ise araştırmacının katılımcılarla soru-cevap kısmı dişında kurduğu iletişim hariç olmak üzere, yalnızca ilk mülakat sorusunun sorulmasından son mülakat sorusuna alınan yanıtın tamamlanmasına kadar geçen süreye yer verilmiştir.

Aşağıdaki Şekil 2 ile davranışsal edinim ana-temasının ağırlıklı kod dağılımı aktarılmıştır. Buna göre gündelik yaşam temasının ön plana çıktı̆̆1, bu tema kapsamında ise; meslek, giyinme ve ulaşım kodlarına nazaran sırasıyla beslenme/damak tadı ve genel kodlarının belirgin bir ağırlık arz ettiği anlaşılabilmektedir.

${ }^{6}$ İki yılda bir, katılımı ifade etmektedir. 


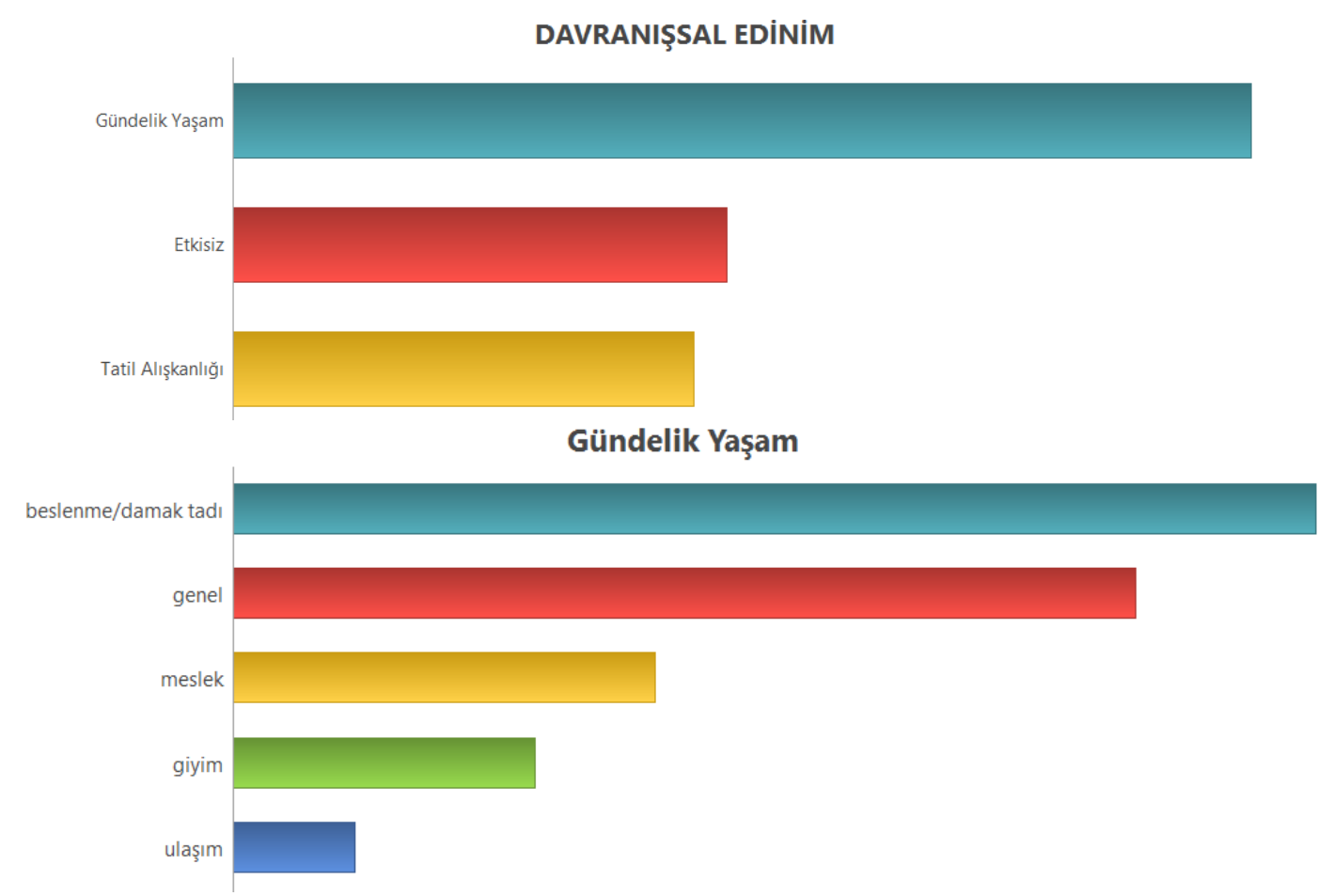

Şekil 1. Davranıssal Edinim Ana-Temasinn Ağrrlkkh Kod Dağgllmı

Turistik deneyimlerin olası kalıcı davranışsal etkilerini ilişki haritası üzerinden işaret eden görsel Şekil 2 vasıtasıyla aktarılmıştır. Bu ilişki haritası; tüm turistik deneyimlerin yine tüm turistler için zorunlu olarak kalıcı davranışsal edinimlere yol açmadığını yansıtmaktadır. Ancak bu durum turist rolünün tamamlanmasının ardından hiçbir kalıcı tesirin bireyin yaşamına yansımadığını da göstermemektedir. Nitekim turistik faaliyetin sona erip tekrar gündelik hayatla birleşildiğinde, turistik deneyimlerin pek çok açıdan bu hayatı farklılaştırdığı, kalıcı biçimde etkilediği tespit edilmiştir. Öyle ki bunlar kategorize edilerek mercek altına alındığında; yeme-içme, giyim, meslek gibi gündelik yaşamın içinde yoğunluklu olarak aktif olan, önemli ölçüde gündelik yaşamın kendisini oluşturan faktörler olduğu görülmüştür.

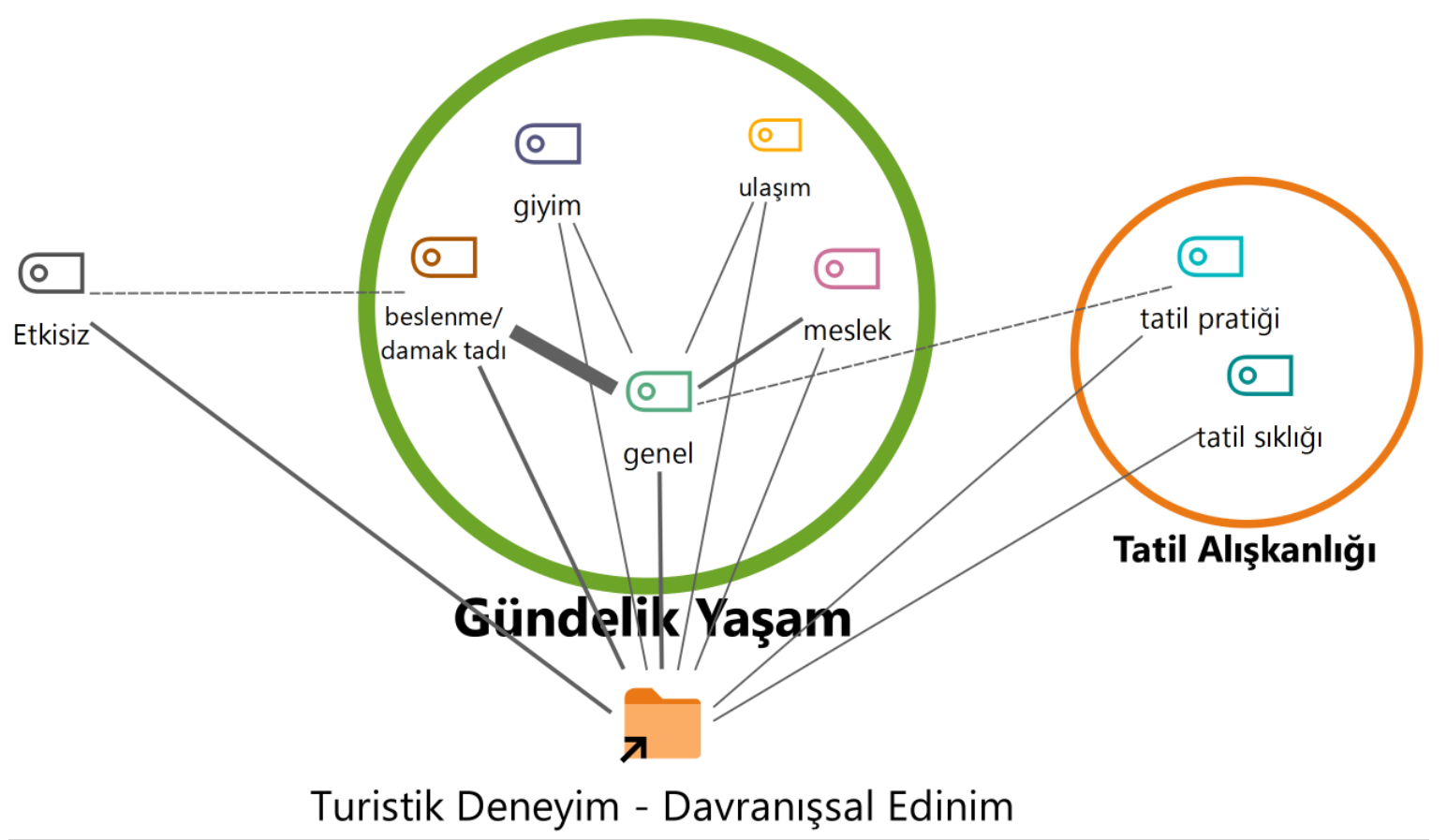

Şekil 2. Turistik Deneyimler ile Davramsssal Edinim Arasındaki Iliş̧ki 
Geçmiş tatil deneyimlerinin, sonraki tatil deneyimleri üzerinde şekillendirici bir rol oynayabileceği not edilmesi gereken bir başka noktadır. Bu hususta turistik deneyimler, yalnızca tatile çıkma motivasyonunu yükseltici ve dolayısıyla tatile çıkma sıklığını arttırıcı değil; bununla birlikte tatil yapma şeklini de farklılaştırabilmektedir. Bunların detaylarına geçmeden önce, her bir mülakat ile ana-tema kapsamında yer alan kod hiyerarşisindeki tüm kodların tek tek ne ölçüde ilişkilendirilmiş olduğunu bütünsel bir şekilde görselleştiren kod matrisine (bkz. Şekil 3) yer verilecektir.

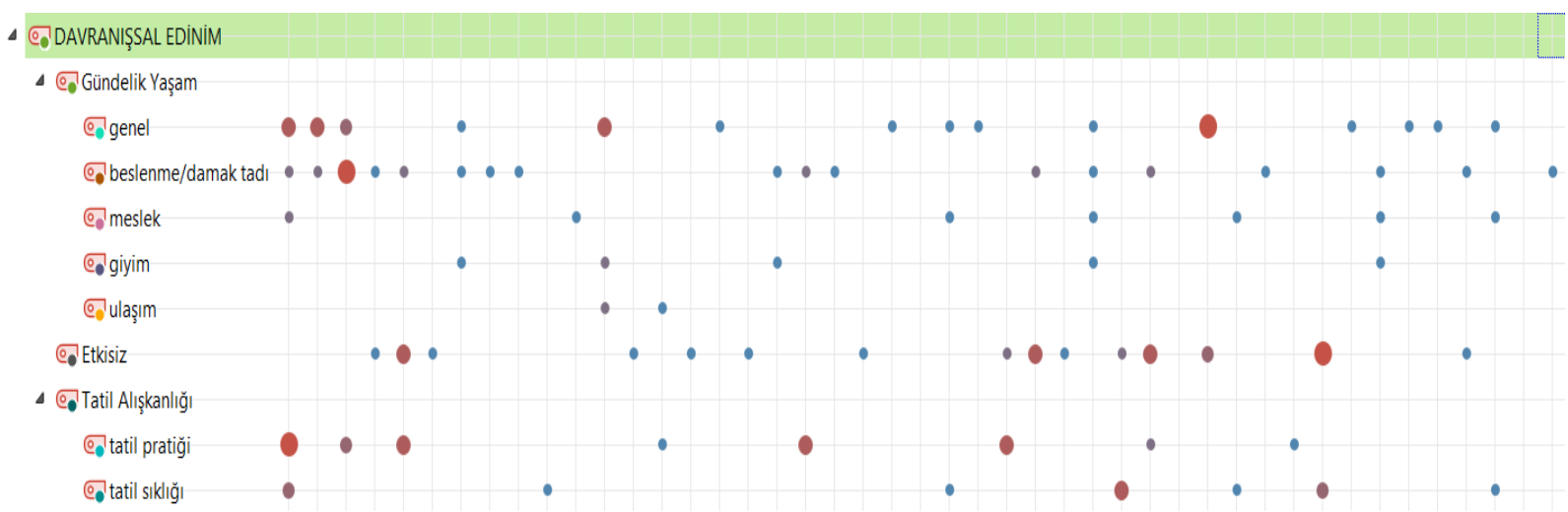

Şekil 3. Davranıssal Edinim Ana-Temasmmn Kod Matrisi

Davranışsal edinim ana-teması mercek altına alınırken, kapsamındaki kodlamaların ağıllkları dikkate alınacaktır. Bu bağlamda sırasıyla gündelik yaşam, etkisiz ve tatil alışkanlığı temaları çerçevesinde bulgular aktarılacaktır.

\section{Gündelik Yaşam: Genel}

Gündelik yaşamın geneline sirayet eden davranış kalıplarının edinilmesine ek olarak kapsamı daha dar, belirli faaliyetler odaklı davranışların öğrenilmesi ve bunların yerleşik hale getirilmesi noktasında da turistik deneyimlerin etkili olduğu anlaşılmaktadır. Turizm vasıtasıyla aşinalık sınırlarının ötesindeki farklı çevresel unsurlarla geçilen etkileşim; öğrenme ve öğrenilenlerin benimsenerek davranışlara ve gündelik yaşama yansıtılması hususunda yüksek marjinal fayda sağlamaktadır. Bu durumu işaret eden veri alıntılarına aşağıda yer verilmiştir.

M40: "Daha rahat davranmayı ögretti bana."

M38: "Konuşma şeklim bile değgști. Bir an bile anlatarak mubabbet edilebiliyor."

M41: "Orada tamidiğm insanlarm vermiş olduğu șeyleri buraya da yansitmaya çalsılyorsun."

M7: "Normalde iki çatal, iki bışakla yemek yiyerek yaşayan biriydim. Eliyle yemek yiyen insanlarla aym ortamda vakit geşire geģire artık öyle insanla da aym masaya oturup karşıllkhl bir şeyler yiyebilirim."

M33: "Kamplara gittikten sonra daba sakin yerleri tercib etmeye bassladim... Internet, telefon gibi seylerden uraklaşmaya başladim... Minimalist yașamm günlïk yaşamma da etkisi olmustur, daba az essya kullanmama sebep olmustur."

M43: "Bir yerde hayvanlara kötü muamele edildig̈ini görïyorsunuz, o sizde çok farkh bir i乏 burakıyor. Sonrasinda kedilere köpeklere karşı, etrafta gördï̈üinüz, hayvanlara karşı daba duyarl olmanızı sağglyor."

M2: "Belki günümü̃de sebirlerde yerlere atılan bir çöp bizi o kadar rahatsz etmiyorken; bir doğal güzelliğe

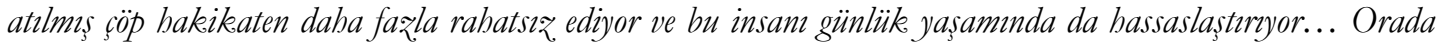
sergilediginiz davranıslar biraz daba kaygisız, ve rahat, bunu günlük hayatumda da uygulamaya çalssyyorum aslinda, keşke oradaki gibi, dünyann disında biraz da kalarak, çok fazla gündem üzerinde dïsïnmeden yaşayabilmeye çalşsyorum."

M16: "Bana yavaşlama sağlad, yani, şehir hayatında herkes koșarak, hareket eder, bir hiə̨n içerisinde olur. Bir hedefe yetismeye çallşan bir halimiz var, her seyahat dönüsünde, her tatil dönüsünde mutlaka yavaşlamıs olurum. Ama çok hizh döneriz geriye, biz de hrzlanmz. Istanbul gibi bir yerde yaşyoruz, yavaslamaya pek bakkemızin olmadiğ bir yerde yasıyoruz: Zaman kistasin mutlaka kullanmak zorundayım, ben uysam da etkileşimde bulunduğum kişilerle uyusamyyorum, ister istemez, ondan sapryorum. Gün içerisinde de, İstanbul'da 
da, tatildeki o zamansızlık hissini, zamanın durduğu hissini yakalamaya çalısırm, o anlardaki gibi bissetmeye çalışırm, o pratiği hayatıma aktarmaya çalışıyorum ama çalışan, dört yaşında bir çocuğu olan bir insan için çok da mümkün olan şeylerden bahsetmiyorum.”

\section{Gündelik Yaşam: Beslenme/Damak Tadı}

Daha önce tadılmamış ya da yerinde yeme fırsatı bulunmamış yiyecek-içeceklerin denenmesi, hatta varlığından haberdar olunmayan yiyecek-içeceklerin tadılması turistik deneyimler vasıtasıyla mümkün olabilmektedir. Yine bireyin alışkın olduğu damak tadının ve yemek kültürünün dışından deneyimler yaşama ihtimali de artmaktadır. Bu deneyimler neticesinde farklı yiyecek-içeceklerin bireyin gündelik yaşamının bir parçası haline gelebildiği aşağıda aktarımı yapılmış olan ilgili veri alıntılarından da görülebilmektedir.

M27: "Tattı̆̆ım lezzetlerin birkaçın evde yapıyorum şu anda."

M39: "Cayı şekersiz icmeye alıștım, şeker bitmiști çünkü, bulamamıstık."

M29: "Masala çaym günlük hayatta da kullanmak, konuştuğumuz gibi."

M8: "Mesela hiç raku içmezdim, ilk defa tatilde içtim ve sonra içmeye devam ettim, yemediğim birkaç şeyi yemeye devam etmisimdir."

M45: "Orada deniz ürünü, ilk defa orada yediysem karidesli makarnayı, burada artık kendim de yapyyorum ya da dısarida da yiyorum."

M19: "Hollanda'daki peynirleri burada da aramaya baslamıstım, her gördügüumde de dikekatimi çeker. Dolayszyla lezzetlerle ilgili böyle seyler oldu.”

M18: "Günlük yaşamımda mesela, yeme terciblerimde değisiklikler oluyor. Başka ülkelerde yediğ̈im, tattığım farkli seyleri burada da aryorum ve arayı bulup burada da yiyebiliyorum."

M9: 'Mesela yemediüin bir şeyi yiyorsun, sonra burada görünce de alabilirsin. Örneğin Bursa'nn kestanesi, iskenderi meşhur, orada yediğinle burada yediüzini karşlaştıryorsun. Farkh yemekler ögreniyorum ve pisirebiliyorum."

M20: 'Yeme içme alıskanlıklarm ciddi ölçüde sekillendirdi. Şunu söyleyebilirim, ssebirde büyümüs, memleketine hic gitmemis biri belki bu alıskanliklar çok daha az benimser. Bu anlamda, yeme icme anlamindaki alıskeanlıklarm etkilemistir."

M7: "Normalde çok fąla yemek seçen biriydim, hala seçiyorum ama eskiye nazaran bence çok daba geliştim. Normalde mantardan nefret ederim ama zorda kalınca yemiş olduğum için, su anda pizza üzerinde örneğin mantar çı.arttırmyorum."

M1: "Diyelim pattai yiyorsun orada, burada da yapyorsun, Hindistan'da mesela chickentikeka masala yedim, ondan sonra onu yapmaya basladim ve bala da yerim. Amerika'da Hint yemekleri sevmiyordum ama Hindistan'a gittikten sonra sevmeye başladım, Hint yemeği yemeye başladım."

M3: "Kuymak vd. yemekleri önceden yememistim, şimdi daba çok yemeye başladım... Tattı̆̆m yemekleri daha sık talep ediyorum... Yurtdısında farklı deniz ürünleri, kabuklu canlılar ilk defa yedim, simdi de gördükçe yiyorum. Daha önce tatmay istemediğim yiyeceklerdi, yemek alıskeanlıklarm değistirebiliyor.”

M5: 'Porto'nun kendine özgü bir şarabı var, onu almak isterim her firsatta. Burada her yerde bulamyorum, belirli noktalarda var, param yettiği müddetçe almayn tercih ederim. O seyahatten önce Porto sarabinm varlı̆̆ından bile haberim yoktu, geldikten sonra belirli bir süre oradaki alışkanlĭ̆g devam ettirmeye çalıștım."

M2: "Yani mesela bu yemeklerde de olabilir. Benim orada tattı̆̆m bir seyi, gelip evde kendim de yapabiliyorum ya da talep edebiliyorum. Örneğin; daha önce yine tatmıs olmama rağmen karides, kalamar gibi deniz ürünlerine karş çok önyargulyydım ve asla yemek istemiyordum, fakat bir tatilim esnasinda yine deneyip bu keez hosuma gitmesi sonucu artı günlük hayatımda da karides ve kalamar yemeyi talep eder hale geldim."

M4: "Şimdi buradaki Kore restoranlarna gidiyorum (sabipleri de Koreli), tonlarca para veriyorum. Yani oradaki kimbab diyelim 1 tl iken; ben burada 45 tl veriyorum ki özellikle her ay burada bütçe aynryorum. 
Mesela yosun yemezdim, şimdi cips gibi yosun yiyorum. Mesela bunu kendi çevreme de yansiyorum, annem

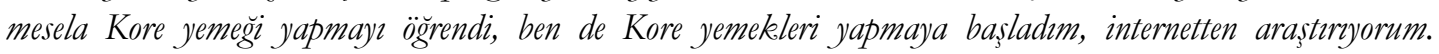
Yiyemezken bu hale geldim, hatta Kore yemek yarısmasına katuldım. Onun gibi tabii ki de bu benim hayatım etkiledi. Şimdi çok rahat Kore yemeği yiyebiliyorum, iğrenc de olsa deniyorum."

\section{Gündelik Yaşam: Meslek}

Turistik deneyimlerin mevcut tam zamanlı işler için zenginleştirici bir rol oynayabileceği, potansiyel (hobi temelli, bkz. M24) yarı-zamanlı iş imkânlarını ortaya çıkarabileceği ve destekleyebileceği, hatta profesyonel yaşamı baskılayabileceği (M39) tespit edilmiştir. Söz konusu baskılamanın bireyin isteği doğrultusunda gerçekleştiği; profesyonel yaşamın aslen birey nazarında kısıtlayıcı, turistik deneyimlerin ise özgürleştirici olarak değerlendirildiği not edilmelidir. Dolayısıyla profesyonel yaşamın baskılanması ifadesi olumsuz bir anlam yüklenmemiştir.

M29: "Bir şeyler katıyordur, çalışmalar açsından da mesela, bir şey olduğu zaman buradan şuradan irtibat kurayım diyorum. Italya'dan Nepal'den, onlarla ilgili bir karşılaştırma yapsak nasıl olur diye düsünüyorum."

M24: "Dalışla tamısmam tatilde oldu, yaşam tarzıma dönüstü. Dalıs eğitmenliği de yapıyorum, tutku haline geldi."

M39: "Dolayısıla elimden geldiğince istifa edip işlerden, 2 ay sonra tekrar işe girerek, o süreleri giderek daha da uzun hale getirmek, kork a korka denize girmek gibi, o son istifay verecek güne yaklasıyorum."

M43: 'Doğu'yu çok gezdim, severek de gezdim. Özellikle Antep ve Urfa bölgesindeki insanlarn dişardan gelen insanlara karşı daha içekapanı olduklarm görmüstüm. Burada ögrencilerim bususunda da bunu fark ediyorum. Bunun kültürel bir seyden kaynaklandı̆̆m tabmin ediyorum. Kültürün karakteri etkilediüzini görüyorum, dolayısıyla onlar acmak için, onlara karşı daha farkl bir yaklaşım sergilemeye çalışyorum. Oradan, onlarn kültüründen, gezdiğinizden babsedebilirsiniz, bu onlarda rahatlama hissi olusturuyor.”

\section{Gündelik Yaşam: Giyim}

Turistik deneyimlerin yalnızca bireylerin gündelik ya da etkinlik-bağımlı (dügün, davet gibi) giyim tercihleriyle değil; aynı zamanda nerede ne giyilmesi hakkında görüşleri ve bu görüşlerin kendi ve çevresindekiler için pratiğe dönüşmesi hususuyla da ilişkili olduğu anlaşılmıştır. İlgili veri alıntıları aşağıda paylaşılmıştır.

M12: "Şimdi daha yürüyüse uygun, spor ayakkabular giviyorum”

M29: "Onlarn kültürel giysilerini aldık, bir dügü̈n falan olsa giverim, çok porlttıl ş̧eyler olduğu için."

M18: "Günlük yaşamda giyinişimde farkhlılaşmaya yol açıyor. Oralarda aldığım şeyleri, örneğin gömlekleri, sapkalar giyiyorum."

M7: "Giyim kuşama çok dikekat ederdim, en ą̧ından masamda olan kişinin, birlikte vakit geçirdiügim kişinin belirli bir klasmanda olmasım tercib ederdim. Bir süre sonra bunlar da görmeyi bırakiyorsunuz: Şu anda yanımda t-shirtle ya da yurtık bir kiyafetle de olsa yadirgamam."

M39: "Pantolonum vard, şort olabiliyordu, işim bu sekilde giyinmemi zorunlu kulmasaydr her gün onu giyebilirdim. Biraz daha o deneyimi sebirde de devam ettirmek, kurntularm alabilmek için istek oluyor. Hem onlara yapısmıs anilar seviyorum hem de hakikaten rahatlar, gerek yok başka bir şeye, dolayısiyla onlar benim üniformam. Sürekli onlar giyiyorum, işe giderken de farklı bir üniforma giyiyorum.”

\section{Gündelik Yaşam: Ulaşım}

Farklı yaşam şekillerini gözlemleme ve etkileşime geçme imkânı tanıyan turistik deneyimler, bireylerin ulaşım tercihlerinin farklılaşmasına etki edebilmektedir. Uygun koşullarda toplu taşıma kullanılmasının; trafik yoğunluğunu azaltması, havanın daha az kirlenmesine katkı sağlaması, kaynakların israf edilmemesi gibi pek çok açıdan olumlu sonuca açıldığı genel olarak bilinen bir durum olmasına karşın, bunu yaşamlarına adapte etmiş bir yerde bulunmak, bunu gözlemlemek hatta bunun bir provasını yapmak bireyin ulaşım tercihlerinin değişmesine vesile olabilmektedir. Bununla birlikte turistik deneyimler kapsamında yaşananların, özel ya da toplu taşıt tercihinin ötesinde taşıt kullanmama tercihi ya da taşıt kullanma sılklı̆̆1 pratiğiyle de ilişkili olduğu görülmüştür. 
M14: "Arabayn daha az kullanmaya başladım. Her Avrupa ülkesine gittig̈imde toplu taşımayı kullanan çok insan olduğuna dik.kat ettim ve toplu taşıma kullanmanın daba mantıkli olduğunu buldum. O da bir artı değer kazandırdı açıkçası bana."

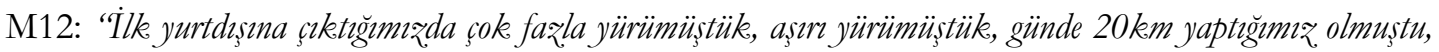
bir şehri tamamen yürüyerek gezmiştik. Her yere giderken otobüs kullanmak zorunda olmadiğım fark ettim. Bu benim günlük yaşamdaki ulaşım alıskanlıklarm değistirdi. Önceden iki durak bile olsa 'ne yürüyeceğim, otobüse bineyim' derdim, simdi bir yere gidiyorum, 'buradan burasi yarm saat, cok urak değil' diyorum. Insanlar 'ne demek yarm saat, otobüse binelim' diyor. O değgssti, onu net olarak söyleyebilirim."

\section{Etkisiz}

Psiko-öznel bir kurgu olan deneyimlerin bireye özgü yap1sı (Smith ve diğ., 2012, s. 484) göz önünde bulundurulduğunda her birey için istisnasız tüm turistik deneyimlerin, davranışsal edinim çerçevesinde gündelik yaşam pratikleriyle zorunlu olarak benzer seviyede ilişkili olamayacağ kabul edilecektir. Nitekim aşağıda yer verilen veri alıntıları, turistik deneyimler vasıtasıyla birey davranışlarının kalıcı olarak etkilenmeyebileceğine ilişkin örnekleri temsil etmektedir.

M30: "Günlük yaşamıma çok da bir katkısı olmadı."

M21: "Tatilde yaşadiğım bir sey buradaki hayatım etkilemez:"

M31: "Alıškanlıklarmda değisen bir sey olduğunu sanmiyorum."

M42: "Tatilleri kendimize uygun seçeriz, o yüzden çok etkilemez:"

M13: "Günlük yasama çok büyük etkisi olmaz... Tatilde olan tatilde kalır."

M5: "Çok keskin değissimler pek hayatımda olmadı̆̆ için, sadece tatil anlayışımı değı̆știrdi."

M6: "Yok, günlük yaşantım etkileyen bir şey olmaz. Beni etkileyen bir yer de olsa, yaşantım etkilemez:"

M15: "Günlük hayatıma yansiyan çok bir şey olmadi... Normal yaşantıma etki etmiyor, düsünce olarak beni genisletiyor."

M28: "Tatil insanın dinlenmesi, soyutlanması bakımından çok önemli. Bana bir şey katması açısından tatilin önemli olduğunu düs̆̈̈müyorum... Tatillerimden etkilenme diye bir şey söz konusu olmadı.”

M17: "Günlük yaşamımda bir değgisiklik olmadı. Kendi yaşamım sürdürebileceğim yerlere gittiŭim için gittiğim yerlerin de bana biç değisile bir katkısı olmad, yine evime, sebrime, ülkeme geldiğimde aym rutinlerle devam ettim."

M37: "Çok etkisi olmadı bence. Tatilin o anlamda katkısı olmadı, büyümekle alakalı, yaşanmışlklarla alakal bir değisime uğruyor insan ama tatilin böyle bir etkisi olduğunu düşünmüyorum... Yani, ilk. zamanlarda biraz etkisi oluyor, biraz daha güzel bakmaya basllyorsun o tatilin etkisiyle ama sonrasinda maalesef tekrar günlük yaşama dönüyor.”

\section{Tatil Alışkanlığı: Tatil Pratiği}

Bir boş zaman etkinliği olması bakımından turistik deneyimlerin tatil alışkanlığı kapsamında tatil pratiği ve tatil sıklığ1 ile ilişkisi; davranışsal edinim dâhilinde, gündelik yaşam haricinde ele alınmıştır. Turistik deneyimlerin bilişsel süreçler ve gündelik yaşam pratikleri üzerindeki (davranışsal) olumlu kalıcı tesirlerin meydana gelmesinde destekleyici, mümkün kılıcı bir payının olması gibi, tatil pratiği üzerinde de benzer etkilerinin olduğu görülmektedir (bkz. ilgili veri alıntıları).

M31: "Tatildeki davranıslarm kesin değisti, ilk gittiğimle şimdiki arasinda çok fark var."

M14: "Evet, yurtdısı tatillerinde git gide daha rahat olmaya başladım, eskiden daha çok geriliyordum"

M3: "İlk keez dağlara, yaylalara çı.ık, deniz̧in dişında olduğu için tatil anlayışımdan farkh geldi ve bu beni etkiledi. Doğanm içinde olmaya daha faz̧la çalıștım."

M36: "Özellikle kamp tatili konusunda bilinçlendirdi, planl olmak, yer seçimi, daha az insanla gitmek gerekir. Kücük bir sorun (uyku) tüm tatili engelleyebiliyor.” 
M26: "2-3 ynl önce bir İzmir gezisine kadar taribi yerler pek, ilgimi çekmezdi. Orada Efes Antik. Kenti”nin de dâbil olduğu bir tur yapmıștık, o biraz etkilemisțti. Bundan sonra gittigim yerlerde bu taribi yerleri görmeye gidebilirim dedim. O beni biraz değģştirdi diyebilirim, o tatildeki değģşiklik."

M19: 'Daha sakin tatilleri sevdig̈imi fark ettim, yalnz olmayn tercih ettig̈imi fark ettim. Tatilin yalnız̨a Bodrum'a Marmaris'e gitmek olmadiğmn, bir koyda da beş gün geşirebildiğimi fark ettim. Kamp tatilinin bana göre olmadiğgn ögrrendim. En ažndan bir tuvalet ve yatağın benim için olmast gerektiğ̈ini ögrrendim... Nelerden boşlamp hoşlanmadrğmı, tatil klişelerinin yersiz olabileceğini, kalabalık tatillerin her zaman iyi olmadiğgn, önemli olan tatile kiminle gittig̈̈n olduğu ya da tek bassına gitmen ve kendi istedig̈in seyi yapmanm önemini ögrendim."

M1: "Ben mesela eskiden gittiğim yerlere çay taşırdem, bulamady̆ğm için mutlaka siyah çay götürürdüm. Ama şimdi gittiğgim yerin içeceğini içiyorum, kesinlik çay götürmüyorum, içmiyorum da. Mesela Thailand'da, en son oraya gittig̈im için orası aklima geliyor, Thailand'damatcha çayn daha güzel, matcha şayn içtim altı gün, şimdi artık, aksine onlarn terciblerini tercib etmeye çalssyorum. Mesela burada ne yeniyor sabab; ballk yeniyor, tamam ben de balık yedim. Ben artık adapte oluyorum, çünkü ancak o şekilde deneyimlediğimi düsünüyorum... Fransa'ya gidiyorsun mesela Lowvre müzesi görülecek, tike at, tik meselesiydi. Ama son zamanlarda tatil deneyimi kazandikşa daha spontan șeylerin daba fazla zevk verdiğini kesfettim, evet, artı coğunlukla spontanm."

M5: "Bundan sonra tatillerimi öyle yapmak isterim. 10-15 gün gidip sabil kenarnda güneslenip oraya sabit kalmaktansa; yurtdlşında daha önce hic görmediğim bir şehir daha cazip olur. Yurt disına gidip 10-15 tane sebri 10 günde put putpit gezmeyi değil; 3-4 gün bir sehre odaklamp oranun her bir tarafin gezmeyi, yemeğine, kültürüne, insanna temas edeyim, öyle gezeyim istiyorum. İki defa öyle yaptom, bundan sonra da bu tarz bir tatil kurgulamayn isterim. Hatta her sene tatil yapmak yerine iki senede bir böyle bir tatil yapıp bu şekilde

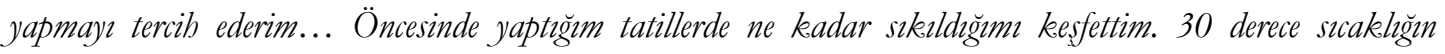
altnda kumsalda bütün gün yatıp, denize girip çıks, o tarz bir tatilin bana uygun olmadiğm gördüm, tercib etmemeye çalssyyorum. Daba çok 10-15 günlük böyle bir tatil planlamaktansa ya da bir yąlğga gidip orada kapalı kalmaktansa 2-3 gün daha önce bic görmediğim bir yerde tatil yapmak. bana daba iyi gelmeye başladr açıksası."

\section{Tatil Alışkanlığı: Tatil Sıklığ1}

Turistik deneyimler kapsamında yaşananların birey için ödüllendirici yönlerinin yüksek olduğu yahut birey tarafından o şekilde algılandığı görülmektedir. Bu ödüllendirici faaliyetlerin bir parçası olunmasına dair sürenin ve sıklığın haliyle arttırılmaya çalışılması makul bir duruma işaret edecektir. Nitekim turistik deneyimlere katılımın yalnızca tatil pratiklerinde farklılaşma sağlayabileceğini değil; tekrar tatile çıkma isteğini, turistik deneyimlemenin arttırlması talebini de tetikleyebildiğini ifade etmek mümkündür. Aşağıdaki ilgili veri alıntıları bu durumu somutlaştırmaktadır.

M37: "Tekerar gitmeyi istiyorum."

M10: "Daba çok gezme/görme isteğim oldu."

M43: "Farkh yerleri görme isteği uyandrryor."

M34: "Tatil ve gezmek olayn kafamda sürekli var ve biçbir zaman da bitmeyecek bu istek."

M30: "O anlar bir daha yaşayabilmek için daha çok gayret sarf etmeme... Oraya gidip farklilĭgr gördü̈üumde, heyecanm bissettigimde, buraya döndï̈ğ̈̈mde ben biraz daha para biriktirip farkh duygular bir daba yasamak istediği fark ettim."

M1: "Ileride daha fazla gezip görme motivasyonumu artturyor. Daba fazla gezince, birkaç yer daba görünce belki daha farkh dïsüneceğim, belki bu beni daha farkh bir yere götürecek diye dïsïnüyorum... O yü̈den berbalde sürekli bir gitme isteği duyuyorum."

Turistik deneyimlerin davranışsal edinim ile ilişkisine dair bulguların başlıklandırılarak detaylandırılmasının ardından çalışmanın nihayete erdirileceği sonuç ve öneriler kısmına geçilmektedir. 


\section{Sonuç ve Öneriler}

Liminal evreye girme sürecini içeren turistik deneyimlerin ardından bireylerin gündelik yaşamlarına genelde birkaç hafta içinde adapte olarak döndüklerinin ve turist rolü oynamanın birey üzerindeki etkisinin ortadan kalktığınınifade edilmesi mümkündür. Bu durum turistikdeneyim temelli tesirlerin de uçucu nitelikte değerlendirilmesine ve etiketlenmesine kap1 aralamıştır. Ancak önemli bir paylaşılmayan çevre unsuru olarak turistik deneyimler ele alındığında (Volo, 2009; Pocock ve McIntosh, 2011; Cohen, 2011) birey için olası etkilerinin uçuculuktan ziyade kalıcllığı çağrıştırdığının altı rahat bir şekilde çizilebilecektir.

Her turistik deneyim kendine has bileşenlerden oluştuğu gibi turistin bu etkinliği daha çok paylaşılan çevre içinde gerçekleştirmesi de olasıdır. Bununla birlikte aşinalık ve konfor arayışıyla gündelik alışkanlıklardan fazlaca ödün vermeden gerçekleştirilen turistik faaliyetlerin benimsenmesi ve bu çerçevede bir turist tipini bireyin somutlaştırması mümkündür. Dolayısıyla bireyin turist rolünden arınıp gündelik yaşama geçişinin tamamlanmasının ardından, turist rolü kapsamında ortaya çıkan etkilerin sönümlenmesi ve bunlardan dikkate değer ölçüde kalıcı bir iz kalmaması da ihtimal dâhilindedir. Çalışmanın odağı çerçevesinde ifade etmek gerekirse; turist rolü oynanırken davranışsal farklılaşmalar gözlense dahi, gündelik yaşamla bütünleşme sürecinin ardından davranış pratiklerinde kalıcı ve belirgin bir farklılaşma gerçekleşmemesi söz konusudur.Nitekim gündelik yaşama dönüş ve normlarıyla bütünleşmeyle birlikte turistik deneyime dair tesirlerin sönümlendiği, bilişsel düzeyde bir edinim söz konusu olabilmesine rağmen davranışsal ölçekte kalıcı bir etkinin mevzubahis olmadığı bazı katılımcıların ifadelerinden anlaşılmaktadır. $\mathrm{Bu}$ hususun alt katmanlarının somutlaştırılabilmesi bakımından, konuya ilişkin odaklı çalışmalar yapılması katkı sağlayıcı olacaktır. Yine de bu durum, turist rolü oynanırken deneyimlenenlerin hiçbir surette kalıcı tesirinin olmayacağını da sabitlememektedir.

Turistik transincenneti dünyaya getirme potansiyeli hayata geçtikçe turistik faaliyetlerin gündelik yaşamdan farklılaşan ve bu bağlamda paylaşılmayan çevre içinde etkinliği arttıran, nihayet ters-yüz olmuş deneyimler yaşatan içeriği ağırlık kazanacaktır (bkz. Jafari, 1987, s. 154). Nitekim literatüre bakıldığında turistik deneyimlerin birey üzerindeki bir anlamda dönüştürücü etkilerinin daha çok paylaşılmayan çevre içinde gerçekleştirilen turistik faaliyetler zemininde gözlemlendiği anlaşılmaktadır (Week, 2012; Richards, 2015; Cohen, 2010a; 2010b; 2010c; Uriely, Yonay ve Simchai, 2002; O’Reilly, 2006).

Turistik deneyimlerin birey üzerindeki etkilerini araştıran literatürü destekler nitelikte, kümülatif turistik deneyimler kaynaklı kalıcı davranışsal edinimlere odaklanılan bu çalışmada; turistik deneyimlerin konuşma şeklinden sosyal çevreye, yeme-içme şeklinden yaşam alanı kullanım tercihine kadar bireyin gündelik yaşamına ve belirli açılardan tatil alışkanlığına kalıcı anlamda etki ettiği noktalar ön plana çıkmıştır. Turistik deneyimler vasitasiyla;

- Gündelik yaşamın geneline sirayet eden -konuşma şekli gibi- davranışsal edinimler sağlanabildiği,

- Farklı yiyecek-içeceklerin bireyin gündelik yaşamının bir parçası haline gelebildiği gibi mevcutların da tüketim şeklinin farklılaşabildiği,

- Yalnızca özel ya da toplu taşıt tercihinin değil, genel anlamda taşıt kullanma tercihinin yahut taşıt kullanma sıklığının etkilenebildiği,

- Tam zamanlı mesleki uğraşların zenginleşebildiği ayrıca potansiyel yarı-zamanlı iş imkânlarının ortaya çıkabildiği, hatta profesyonel yaşamın baskilanabildiği,

- Giyim tercihlerinin ve giyime ilişkin görüşlerin değiştirilebildiği,

- Tatil pratiklerinin ve tatile çıkma sıklığının şekillenebildiği ortaya konulmuştur.

Buradan hareketle, bir paylaşılmayan çevre unsuru olarak turistik deneyimlerin bireye farklı yaşam pratiklerinin mümkün olduğunu gösteren, onun hareket alanını arttıran değerli bir unsur olduğunun ifade edilmesi mümkündür.

Yürütülen araştırmayla, genel anlamda psikoloji perspektifiyle turizm alanında araştırmalar yürüterek ilgili alanda eser veren yazarların(Light, 2001, s. 1054; S. Larsen, 2007, s. 7; Pearce, 2010, s. 251; Pearce ve Packer, 2013, s. 388), konuya ilişkin araştırmaların arttırılmasını önerdiği bir noktaya mercek tutulmaya çalışılmıştır. Bununla birlikte turizm alanındaki temel özne pozisyonundaki turiste odaklanılması ve kümülatif turistik deneyimlerin, turist için turizm olayının ötesine taşarak ne anlam taşıdığ1 ve ne gibi somut çıktılar ortaya koyduğunun incelenmesi, çalışmanın arz ettiği öneme işaret etmektedir. Ancak bu çalışmanın ilerlediği yolun, diğer araştırmacılar tarafindan ilişkili araştırma soruları ile genişletilmesi ve derinleştirilmesi, esas değerin ortaya çıkarılması hususunda elzem bir paya sahip olacaktır. Bu doğrultuda; 
- Farklı kriterler nezdinde kategorize edilmiş tipolojiler tabanında turistik deneyimlerin dikkate alınmasi,

- Turistik deneyimler temelinde kazanılan davranışsal edinimlerin derinleştirilmesine ek olarak bilişsel edinimlerin (Falk, Ballantyne, Packer ve Beckendorff, 2012; Erdoğan ve Kıngır, 2019) ve diğer bireyin benliğinde önem arz eden faktörlerin değerlendirilmesi,

- Turistik deneyimlerin, Pearce ve Lee'nin (2005) seyahat kariyerinde olduğu gibi birikimselolarak ele alınmas1,

- Gündelik yaşam ile turist rolünün/turistik yaşamın (Aktaş Polat ve Polat, 2016) ne ölçüde birbirinden ayrrlabileceğinin yahut yaşam çemberinin içindeki yerlerinin düşünülmesi,

- Gerçekleştirilen turistik deneyimlerin -dönüştürücü olsun olmasın- tesirlerinin, o deneyimlerin öznesi olarak turiste ve nesnesi olarak turist ağırlayan yerel halka yansımalarının (Bruner, 1991) karşılaştırmalı bir şekilde irdelenmesi,

- Turist rolünün gündelik yaşama dönüşün ardından etkinliğini ne seviyede koruduğunun incelenmesi,

- Turist rolünün sönümlenmesine etki eden hızlandırıcı ve yavaşlatıcı esas faktörlerin tespit edilmesi gibi konulara araştırmacılar tarafindan ilgi gösterilmesinin faydalı olacağ1 düşünülmektedir.

Turisti odak noktasına alan çalışmaların deneyim ekonomisi (Pine ve Gilmore, 1998) çerçevesinde ele alınan turizmin (Oh, Fiore ve Jeoung, 2007; Andersson, 2007) ve turistik ürünlerin her ölçekte daha iyi kavranabilmesi ve şekillendirilebilmesinde etkili olacağı aşikârdır. Bununla birlikte turistik deneyim odağının, ilgili teorik ve pratik açılımlarıyla bütüncül bir katkıya giden yolun çıkış noktası olarak değerlendirilmesi de mümkündür. Buradan hareketle turist perspektifinden turizm olay ve olgusunu irdeleyen araştırma sorularının çeşitlendirilmesinin ve turisti merkeze alacak şekilde yürütülen araştırmaların arttırılmasının arz edeceği kıymet vurgulanmaktadır.

\section{Etik Beyan}

"Liminal Evrenin Ardindan: Kümülatif Turistik Deneyimler Temelinde Kahcı Davranıssal Edinimler" başlıklı çalışmanın yazım sürecinde bilimsel, etik ve alıntı kurallarına uyulmuş; toplanan veriler üzerinde herhangi bir tahrifat yapılmamış ve bu çalışma herhangi başka bir akademik yayın ortamına değerlendirme için gönderilmemiştir. Bu araştırmanın verileri 01.01.2020 tarihinden önce toplandığı için etik kurul kararı zorunluluğu taşımamaktadır.

\section{Not}

ExtendedAbstract kısmını desteklemesi bakımından çalışmada aktarılmış olan şekillerin İngilizcelerine aşağıda yer verilmiştir.

In order to assist Extended Abstract part, the conveyed figures within the study included below once again in English.

BEHAVIORAL ACQUSITION

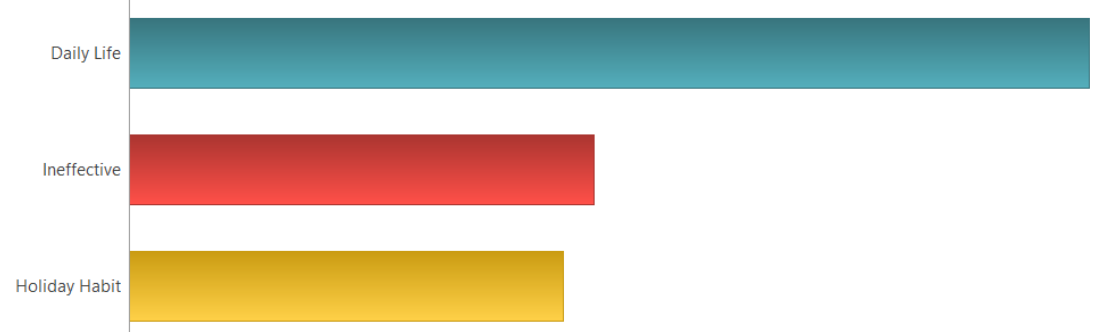




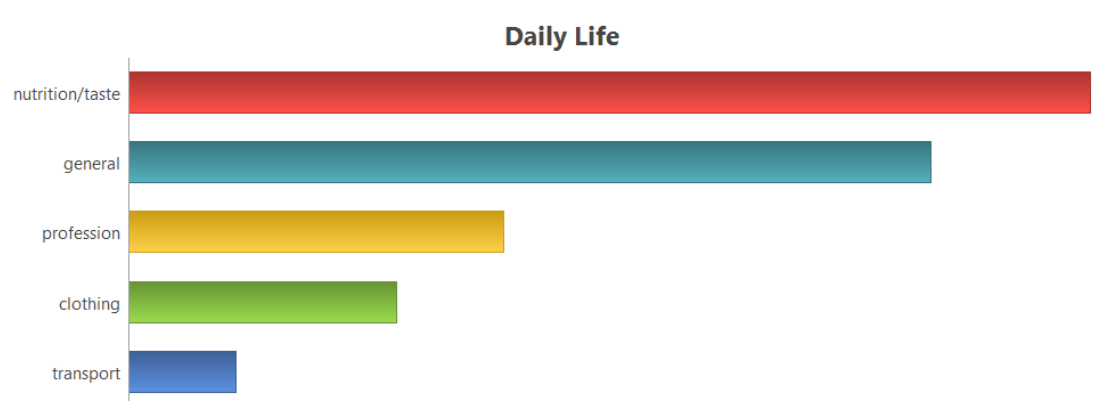

Figure 1. Weighted Code Distribution of the Behavioural Acquisition Main-Theme

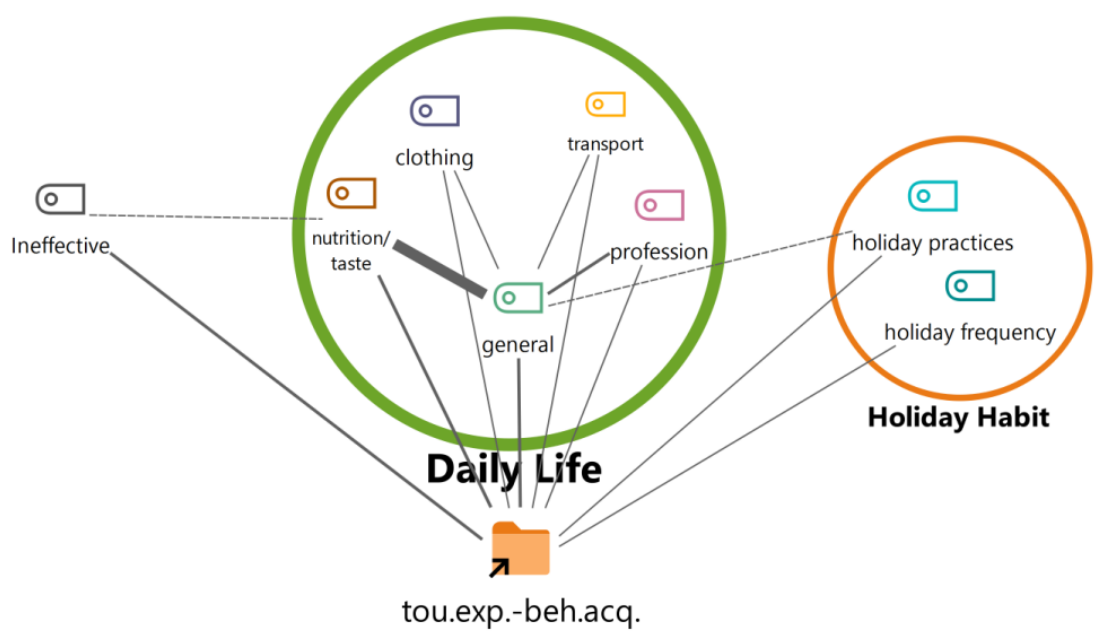

Figure 2. The Relationship between Touristic Experiences and Behavioural Acquisition

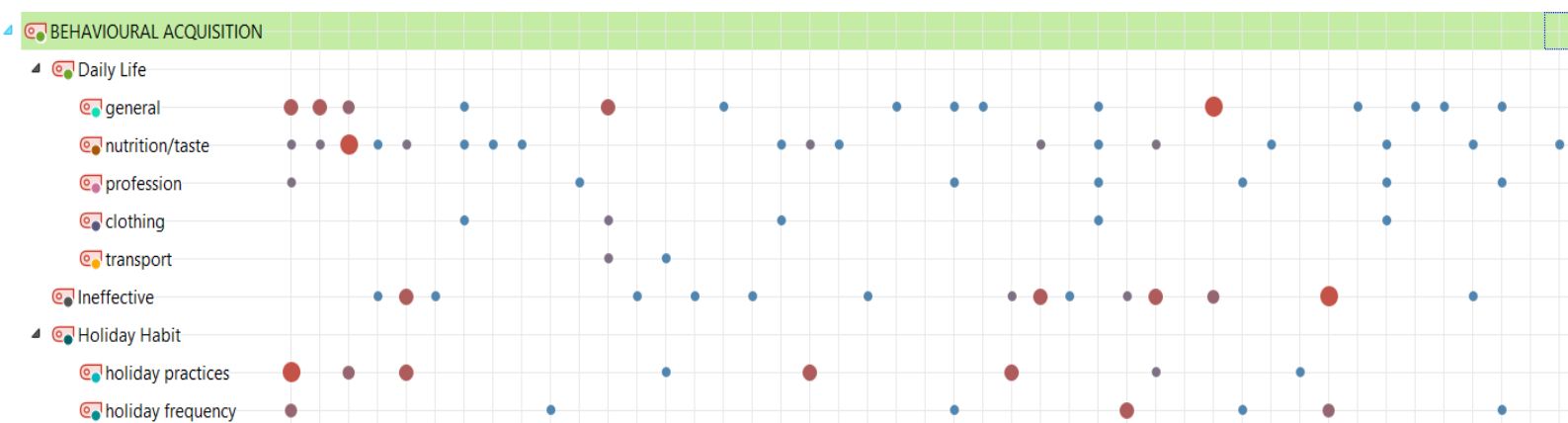

Figure 3. Code Matrix of the Behavioural Acquisition Main-Theme

\section{Kaynakça}

Aktaş Polat, S. (2013). Turistlerin Tatil Dönemlerinde Sergiledikleri Geçici Davranış Değişiklikleri (Liminoid)

Üzerine Bir Araştırma (Doktora Tezi). Sakarya Üniversitesi Sosyal Bilimler Enstitüsü, Sakarya

Aktaş Polat, S. (2015). Turistlerin tatil dönemlerinde sergiledikleri liminoid ., Sosyoekonomi, 23(26), 99-117.

Aktaş Polat, S., ve Polat, S. (2016). Turizm perspektifinden yabancılaşmanın sosyo-psikolojik analizi: Günlük yaşamdan turistik yaşama yabanc1laşma döngüsü. Sosyoekonomi, 24(28), 235-253.

Andersson, T. D. (2007). The tourist in the experience economy. Scandinavian Journal of Hospitality and Tourism, 7(1), 46-58.

APA Dictionary (2020). Acquisition. Retrieved October 13, 2020, from https://dictionary.apa.org/acquisition.

Bigger, S. (2009). Victor Turner, liminality, and cultural performance. Journal of Beliefs \& Values, 30(2), $209-212$.

Bond, N. ve Falk, J. (2013). Tourism and identity-related motivations why am I here (and not there)? International Journal of Tourism Research, 15(5), 430-442. 
Bozcuk, A. N. (2005). Genetik (2. Bask1). Ankara: Palme Yayınları.

Bruner, E. M. (1991). Transformation of self in tourism. Annals of Tourism Research, 18(2), 238-250.

Cohen, S. A. (2010a). Chasing a myth? Searching for 'self' through lifestyle travel. Tourist Studies, 10(2), 117-133.

Cohen, S. A. (2010b). Personal identity (de)formation among lifestyle travellers: A double-edged sword. Leisure Studies, 29(3), 289-301.

Cohen, S. A. (2010c). Searching for escape, authenticity and identity: Experiences of 'lifestyle travellers'. In M. Morgan, P. Lugosi and J. R. B. Ritchie (Eds.). The tourism and leisure experience: consumer and managerial perspectives (pp. 27-42), Bristol: Channel View Publications.

Cohen, S. A. (2011). Lifestyle travellers: Backpacking as a way of life. Annals of Tourism Research, 38(4), 1535-1555.

Conti, E. ve Heldt Cassel, S. (2020). Liminality in nature-based tourism experiences as mediated through social media. Tourism Geographies, 22(2), 413-432.

Creswell, J. W. (2016). Nitel araştırma yöntemleri: Beş yaklaşıma göre nitel araştırma ve araştırma deseni (Çev. Edt: M. Bütün ve S. B. Demir) (3. Basımdan Çeviri). Ankara: Siyasal Kitabevi.

Dann, G. M. S. (1977). Anomie, ego-enhancement and tourism. Annals of Tourism Research, 4(4), 184-194.

Desforges, L. (2000). Traveling the world: Identity and travel biography. Annals of Tourism Research, 27(4), 926-945.

Edensor, T. (2000). Staging tourism: Tourists as performers. Annals of Tourism Research, 27(2), 322-344.

Edensor, T. (2001). Performing tourism, staging tourism: (Re) producing tourist space and practice. Tourist Studies, 1(1), 59-81.

Edensor, T. (2007). Mundane mobilities, performances and spaces of tourism. Social \& Cultural Geography, 8(2), 199215.

Erdoğan Ç. ve Kıngır, S. (2019). Turistik deneyimlerin bilişsel edinim bağlamında değerlendirilmesi. Social Sciences Studies Journal, 5(48), 6074-6084.

Falk, J. H., Ballantyne, R., Packer, J. ve Benckendorff, P. (2012). Travel and learning: A neglected tourism research area. Annals of Tourism Research, 39(2), 908-927.

Feldman, R. S. (1997). Essentials of understanding psychology (Third edition). The McGraw-Hill Companies, Inc.

Gottlieb, A. (1982). Americans' vacations. Annals of Tourism Research, 9(2), 165-187.

Graburn, N. H. (1983). The anthropology of tourism. Annals of Tourism Research, 10(1), 9-33.

Horn, L. R. (2018). Contradiction. The Stanford encyclopedia of philosophy (Winter 2018 Edition), Edward N. Zalta (Ed.), retrieved October 13, 2020, from https://plato.stanford.edu/entries/contradiction/.

Jafari, J. (1987). Tourism models: The sociocultural aspects. Tourism Management, 8(2), 151-159.

Larsen, J. (2008). De-exoticizing tourist travel: Everyday life and sociality on the move. Leisure Studies, 27(1), 21-34.

Larsen, S. (2007). Aspects of a psychology of the tourist experience. Scandinavian Journal of Hospitality and Tourism, 7(1), 7-18.

Light, D. (2001). 'Facing the future': Tourism and identity-building in post-socialist Romania. Political Geography, 20, 1053-1074.

Merriam-Webster. (2020). Oxymoron. In Merriam-Webster.com dictionary. Retrieved October 13, 2020, from https://www.merriam-webster.com/dictionary/oxymoron.

Noy, C. (2004). This trip really changed me: Backpackers' narratives of self-change. Annals of Tourism Research, 31(1), 78-102.

O’Reilly, C. C. (2006). From drifter to gap year tourist: Mainstreaming backpacker travel. Annals of Tourism Research, 33(4), 998-1017.

Oh, H., Fiore, A. M. ve Jeoung, M. (2007). Measuring experience economy concepts: Tourism applications. Journal of Travel Research, 46(2), 119-132.

Pearce, P. L. (2010). New directions for considering tourists' attitudes towards others. Tourism Recreation Research, 35(3), 251-258.

Pearce, P. L. ve Lee, U. I. (2005). Developing the travel career approach to tourist motivation. Journal of Travel Research, 43(3), 226-237.

Pearce, P. L. ve Packer, J. (2013). Minds on the move: New links from psychology to tourism. Annals of Tourism Research, 40, 386-411.

Pine, B. J. ve Gilmore, J. H. (1998). Welcome to the experience economy. Harvard Business Review, July-August, Reprint Number: 98407, pp. 97-105.

Plomin, R. (2011). Commentary: Why are children in the same family so different? Non-shared environment three decades later. International Journal of Epidemiology, 40(3), 582-592.

Plomin, R., Asbury, K. ve Dunn, J. (2001). Why are children in the same family so different? Nonshared environment a decade later. The Canadian Journal of Psychiatry, 46(3), 225-233.

Plomin, R., Chipuer, H.M. ve Neiderhiser, J. M. (1994). Behavioral genetic evidence for the importance of nonshared environment. In E.M. Hetherington, D. Reiss, \& R. Plomin (Eds. Separate social worlds of siblings. The impact of non-shared environment on development. Hillsdale, NJ: Erlbaum. 
Pocock, N. J. ve McIntosh, A. J. (2011). The return from travel: A new beginning? Current Issues in Tourism, 14(7), 631-649.

Quan, S. ve Wang, N. (2004). Towards a structural model of the tourist experience: An illustration from food experiences in tourism. Tourism Management, 25(3), 297-305.

Richards, G. (2015). The new global nomads: Youth travel in a globalizing world. Tourism Recreation Research, 40(3), 340-352.

Smith, E. E., Hoeksema S. N., Fredrickson B. L. ve Loftus G. R. L. (2012). Atkinson ve Hilgard Psikolojizye Giriş (Atkinson \& Hilgard's Introduction to Psychology, 2003) (Çev. Ö. Öncül ve D. Ferhatoğlu, (Genişletilmiş ve Güncelleştirilmiş 14. Edisyon). Ankara: Arkadaş Yayınevi.

TDK. (2020a). "Oksimoron”. https://sozluk.gov.tr/, E.T.: 13.10.2020.

TDK. (2020b). "Edinim”. https://sozluk.gov.tr/, E.T.: 13.10.2020.

Turkheimer, E. ve Waldron, M. (2000). Nonshared environment: a theoretical, methodological, and quantitative review. Psychological Bulletin, 126(1), 78.

Turner, V. (1974). Liminal to liminoid, in play, flow and ritual: An essay in comparative symbology. In E. Norbeck (Ed.), The Anthropological Study of Human Play, 60(3), 53-92, Rice University Studies.

Turner, V. W. (1991). The ritual process: Structure and anti-structure. New York: Cornell University Press.

Uriely, N. (2005). The tourist experience: Conceptual developments, Annals of Tourism Research, 32(1), $199-216$.

Uriely, N., Yonay, Y. ve Simchai, D. (2002). Backpacking experiences: A type and form analysis, Annals of Tourism Research, 29(2), 520-538.

Van Gennep, A. (1960). The Rites of Passage, tr. Vizedom, M. B. and Caffee, G. L., Chicago: University of Chicago Press.

Volo, S. (2009). Conceptualizing experience: A tourist based approach. Journal of Hospitality Marketing \& Management, $18,111-126$.

Week, L. (2012). I am not a tourist: Aims and implications of 'traveling'. Tourist Studies, 12(2), 186-203.

White, N. R. ve White, P. B. (2004). Travel as transition: Identity and place. Annals of Tourism Research, 31(1), $200-218$.

Yin, R. K. (2013). Validity and generalization in future case study evaluations. Evaluation, 19(3), 321-332.

\section{EXTENDED ABSTRACT}

In the manner that the liminal/threshold stage of Van Gennep (1960) suggests, standard behavioural patterns are abandoned while the tourist role -which puts emphasis on extraordinariness as compared to the daily life, the carrier of ordinariness pennant- (Edensor, 2000, p. 325) is active as Aktaş Polat (2015) also examined. Experiences within the scope of ritualistic tourism game (Graburn, 1983) and thus emergent new roles, consequently, will be largely invisible when incorporation to the daily life is completed. Nevertheless, it can provide an opportunity to diversify the reflection passes through the daily life norm prism by -at the very least- stretching and reinterpreting these mentioned norms (Desforges, 2000; White, \& White, 2004; Pocock, \& McIntosh, 2011; Bond, \& Falk, 2013; Pearce, \& Packer, 2013).

Despite the fact that the daily life and tourism cannot coexist peacefully since their existence demands particular time and space, and they stand out with contrast when brought together; as Turner's (1991, p. 97) depicture of the natural cycle of the social life generates an undulant view, they represent differentiating points of a continuous wavy lifeline as it can be understood from Edensor's (2000, p. 341; 2001, p. 59) statements and Jafari's (1987) modelling.

The main point of departure to design the research, with reference to the flares that are on the literature (Dann, 1977; Uriely, 2005; Edensor, 2007; J. Larsen, 2008), was to make a contribution by unearthing the embodiment of the lasting impacts of touristic experiences as a non-shared environment that is also called unique, specific or individual environment (Plomin, 2011, p. 583)-element on the daily life practices in the context of behavioural acquisition although they are appeared contactless and opposite two parts from the certain aspects.

A qualitative research method was used to conduct the research with multiple case studies. Data were obtained by utilising the conducted 45 face-to-face interviews via formed semi-structured interview questions within the maximum diversity sampling. Peer review, external audits (Creswell, 2016, p. 250253) and should also be noted that data source triangulation (Yin, 2013, p. 323-324) incorporated into the study. Furthermore, all kinds of tangible and digital components of the data used throughout the research were stored and saved in order to ensure confirmability. The analysis processes were completed via a computer-aided data analysis program for qualitative and mixed methods, MAXQDA Analytics Pro v.18.2. 
It is seen that authors of the related studies invited the researchers to contribute to deepen the field, and guiding suggestions are made by them, stressing the need for the further researches not only on touristic experience and acquisitions regarding this matter but also on tourism field from a broad psychological perspective (S. Larsen, 2007, p. 7; Pearce, 2010, p. 251; Pearce, \& Packer, 2013, p. 388). Accordingly, the effort to embody in what extent the cumulative past touristic experiences have permanent effects on individual's daily life practices in the context of behavioural acquisition, and hence pointing out the integrity and connection of the two wavy points of the lifeline thought to be beneficial.

It is understood that touristic activities are effective to acquire behavioural patterns which reflect on the daily life not only in a general but also in more focused, narrow-scoped manner and make them permanent. Interacting with various environmental elements that are beyond the familiarity verge has a rather marginal benefit on learning and adopting, therewithal actualizing the learned. In this direction, touristic experiences permanently effect some points of individual's daily life ranging from the manner of speaking to forming the social environment, from the eating style/habit to space using preference and so forth. By including concrete examples, it is set forth that; different food and beverages can be a part of the individual's daily life as well as the already preferred consuming manners can be changed, the preference to not use or the frequency to use a vehicle -beyond the private or public transport preferences- can be effected, full-time professional occupations can be enriched, additionally part-time business opportunities can be appeared, also the professional life can be suppressed, the clothing preferences and opinions about clothing can vary, the holiday practices and going on holiday frequency can be reshaped via touristic experiences. It is possible to state that as a non-shared environment element, touristic experiences can reveal different life practices' possibilities and able to extend the area of activity.

The studies focus on the tourist can be effective on grasping and forming the tourism and the touristic product discussed within the frame of the experience economy (Pine, \& Gilmore, 1998; Oh, Fiore, \& Jeoung, 2007; Andersson, 2007) better in every aspect, also can be seen as the gate opens to the road leading a holistic contribution by their related theoretical and practical expansions. 